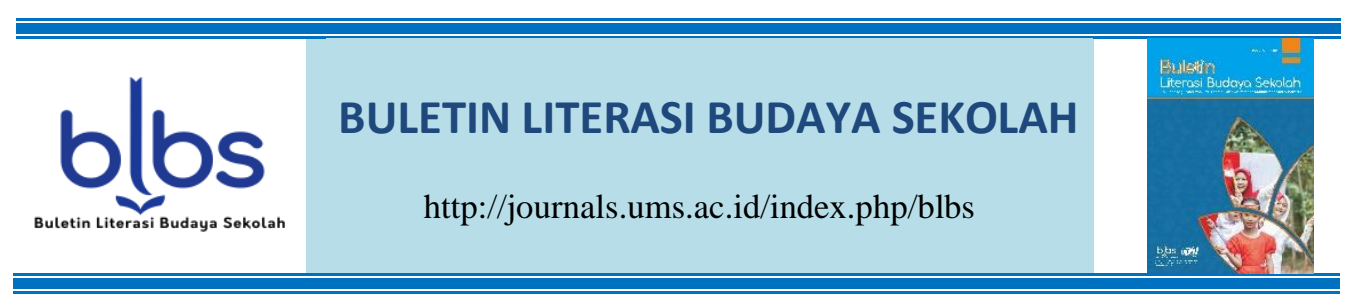

\title{
PENGEMBANGAN SPEAKING SKILL MELALUI KEGIATAN VISITING FOREIGNERS
}

\author{
Dwi Setyo Astuti ${ }^{1}$, Eka Viola Setyowati ${ }^{2}$, Zahratul Fadil ${ }^{3}$, Fildzah Tita Adani ${ }^{4}$ \& \\ Ayu Wijiastuti ${ }^{5}$ \\ 1,2,3,4,5 Universitas Muhammadiah Surakarta \\ Jl. Ahmad Yani Tromol Pos I, Surakarta, Indonesia \\ Email \& Phone: dsa122@ums.ac.id +6281548719313
}

Submitted: 2020-09-07

DOI: $10.23917 /$ blbs.v2i2.12841

Accepted: 2020-09-29

Published: 2020-12-07

\begin{tabular}{ll}
\hline Keywords: & \multicolumn{1}{c}{ Abstract } \\
\hline $\begin{array}{l}\text { visiting } \\
\text { foreigner }\end{array}$ & The ability to speak English or speaking skills is one aspect of \\
speaking skill & learning a language. There are various things that can be done \\
students' & to develop students' speaking skills, one of which is visiting \\
confidence & foreigners conducted by SMK N 1 Banyudono in the English \\
& Conversation Club extracurricular activities. This is done so that \\
& students get a provision for communication in English so that \\
& when students graduate from school as graduates of \\
& vocational school students have provision of communication \\
& skills both in the native language and English as a foreign \\
& language. After this activity is carried out, a follow-up activity \\
& will be held, where students make reports and presentations \\
& about the conversations they have had so that students can \\
& evaluate the activities that have been carried out. \\
& Furthermore, this activity is considered quite important and \\
& must be continued in addition to developing speaking skills, \\
this activity can also develop students' confidence.
\end{tabular}

\section{PENDAHULUAN}

Bahasa Inggris merupakan salah satu bahasa yang dianggap perlu untuk dikuasai setiap individu pada era ini, dikarenakan segala aspek kehidupan sosial masyarakat yang terus berkembang dan memerlukan bahasa Inggris sebagai sarana komunikasi. Salah satu hal yang perlu dikuasai dalam penguasaan bahasa Inggris adalah kemampuan berbicara bahasa Inggris terbagi menjadi empat bagian yaitu kemampuan mendengarkan (listening), berbicara (speaking), membaca (reading) dan menulis (writing) (Uchihara, 2018). Empat kemampuan ini dibagi menjadi dua kategori yaitu kategori receptive skills atau kemampuan menerima input seperti listening dan reading, dan kategori productive skills atau kemampuan menggunakan bahasa yaitu speaking dan writing. Speaking atau berbicara merupkan kegiatan menyampaikan informasi kepada lawan bicara yang didalam 
kegiatannya menggunakan pengucapan yang benar, lancar tanpa adanya banyak jeda, tata bahasa yang tepat,

Tarigan dalam Lestari (2018:109) mendefinisikan keterampilan berbicara sebagai kemampuan mengungkapkan bunyi-bunyi artikulasi atau kata-kata untuk mengekspresikan, menyatakan, serta menyampaikan pikiran, gagasan, dan perasaan. Jadi, berbicara adalah sebuah kegiatan yang dilakukan seseorang kepada orang lain tentang suatu hal atau kegiatan percakapan yang dilakukan seseorang kepada orang lain. speaking skill one of the most important skill that must be mastered by the language learners, it because of speaking plays important role in learning language, it helps people to communicate with each others (Terasne \& Setianingsih, 2020:151).

Keterampilan berbicara memiliki peranan penting dalam upaya melahirkan generasi masa depan yang cerdas, kreatif, kritis dan berbudaya. Keterampilan berbicara juga mampu membentuk generasi masa depan yang kreatif sehingga mampu berbicara yang komunikatif, jelas, runtut, mudah dipahami. Selain itu, keterampilan berbicara juga mampu melahirkan generasi masa depan yang kritis karena mereka memiliki kemampuan untuk mengekspresikan gagasan, pikiran, atau perasaan kepada orang lain secara runtut dan sistematis (Permana, 2015:133). ketika seseorang belajar keterampilan berbicara dapat dipastikan dia juga akan mendengar bahasa target, mencoba membaca tulisan dari apa yang dikatakan, dan kembali menuliskan apa yang sudah dibicarakannya (Ramadhani dkk, 2016:327).

Bicara merupakan keterampilan mental motorik sebagai salah satu bagian dari keterampilan bahasa, yang tidak hanya melibatkan koordinasi kumpulan otot mekanisme suara yang berbeda, tetapi juga mempunyai aspek mental yakni kemampuan mengaitkan arti dengan bunyi yang dihasilkan (Meylinda dkk, 2016:258). Keterampilan berbicara (speaking skill) merupakan suatu keterampilan seseorang untuk menyampaikan hasrat dan pemikirannya kepada siapa saja melalui lisan, akan tetapi, keterampilan berbicara sulit berkembang kalau tidak dilatih secara terus menerus dan bisa dilakukan dengan rekan-rekan di dalam kelas, guru maupun dosen. Tujuannya untuk memperlancar keterampilan berbicara, memperkaya penggunaan kosa kata, memperbaiki tatanan berbahasa, menyempurnakan ucapan-ucapan kosa kata, kalimat-kalimat melatih pendengaran sehingga mudah menangkap pesan dari lawan bicara (Prayitno dan Ayu, 2018:60).

Kemampuan berbicara (speaking) bagi kebanyakan orang adalah kemampuan yang sangat sulit karena meliputi banyak aspek dari kemampuan berbahasa Inggris antara lain pronunciation (pengucapan), listening (mendengarkan), grammar (tata bahasa) dan vocabulary (kosakata) sekaligus (Alim, 2018). Speaking skill biasanya dikuasai setelah menguasai listening skill (mendengarkan), karena pada umumnya, setelah seseorang mendengarkan maka dia akan menciptakan sebuah "produk bahasa" yaitu berbicara (Biria, 2018). Melalui speaking, seorang speaker (pembicara) berkomunikasi untuk menyampaikan maksud dan tujuannya.

Beberapa hal yang menjadi alasan dipilihnya kegiatan untuk pengembangan speaking skill adalah : 1) bahasa Inggris merupakan bahasa yang harus dikuasai oleh seseorang dalam era kehidupan yang dinamis ini, 2) Speaking skill merupakan kemampuan berbahasa Inggris yang dianggap menjadi faktor keberhasilan seseorang belajar bahasa inggris 3) Kegiatan berdialog dengan penutur asli oleh siswa sangat diperlukan untuk mengasah ketrampilan berbicara siswa (Yosnino, 
2014). Melalui kegiatan ini diharapkan dapat diketahui metode pembelajaran bahasa Inggris yang efektif guna pengembangan speaking skill. Selain itu kegiatan ini juga bertujuan untuk mengetahui manfaat dan indicator keberhasilan berdialog dengan penutur asli dalam pengembangan speaking skill.

\section{METODE}

\section{Tempat dan Waktu}

Kegiatan ini dilaksakan pada masa Pengenalan Lingkungan Persekolahan 1 (PLP 1) dalam rentang waktu 28 Januari- 11 Februari 2020 di SMK N 1 Banyudono.

\section{Metode dan Desain Pelaksanaan}

Metode yang dilakukan dalam kegiatan ini adalah Etnografi yaitu mendalami pemahaman siswa mengenai materi dan alur praktek kemampuan berbicara bahasa Inggris. Dan juga dilakukan observasi seperti wawancara dan diskusi mengenai alur praktik berbicara bahasa Inggris dengan orang asing.

\section{Prosedur Pelaksanaan Kegiatan}

Tahap - tahap pelaksanaan kegiatan visiting foreigner dalam pengembangan speaking skill :

\section{Persiapan dan Perencanaan}

Dalam tahap ini penulis melakukan persiapan dan perencanaan guna memperlancar kegiatan observasi yang akan dilakukan, kegiatan yang dilakukan diantaranya :

a. Menetapkan tujuan observasi.

b. Menatapkan obyek yang akan diobservasi.

c. Menentukan instrument dalam mengadakan observasi.

\section{Pelaksanaan}

Dalam tahap pelaksanaan observasi kegiatan yang dilakukan diantaranya:

a. Melakukan pengamatan, dimana penulis melakukan observasi secara langsung dengan cara masuk kedalam kedalam kelas dan mengamati kondisi kelas.

b. Mengumpulkan data dari hasil pengamatan.

c. Melakukan wawancara dengan guru dan siswa.

\section{Pengolahan Data}

Dalam tahap pengolahan data penulis melakukan analisa dan evaluasi data yang diperoleh dari hasil observasi dan wawancara obyek.

\section{Diskusi Hasil Pengamatan}

Dalam tahap ini penulis melakukan diskusi mengenai hasil analisa dan evaluasi data yang diperoleh.

\section{Penyusunan Laporan}

Setelah dilakukan diskusi dan mendapatkan hasil diskusi yang matang, penulis melakukan penyusunan laporan guna melaporkan hasil observasi mengenai pengembangan speaking skill di SMK N 1 Banyudono melalui kegiatan visiting foreigner dalam bentuk PKM-Al. 
Kendala yang ditemui dalam kegiatan visiting foreigner adalah siswa merasa tidak percaya diri ketika berbicara bahasa Inggris dengan orang asing (foreigner). Permasalahan lain adalah ketika siswa sedang berdialog dengan orang asing, siswa terpaku dengan tata bahasa (grammar), pelafalan (pronounciation), dan dialek (accent) sehingga mereka berbicara merasa tidak percaya diri dan malu ketika bertanya seperti kesulitan memahami arti, kosa kata, dialek dan semacamnya. Oleh karena itu, follow up dari kegiatan ini adalah siswa akan mengumpulkan laporan dan presentasi mengenai percakapan mereka dengan foreigners yang mereka jumpai.

Kegiatan visiting foreigner merupakan salah satu kegiatan wajib yang diwadahi oleh SMK N 1 Banyudono dalam kegiatan ekstrakulikuler English Conversation Club $(E C C)$ sebagai upaya untuk meningkatkan kemampuan berbahasa Inggris siswa. Hal ini dilakukan karena SDM didaerah tersebut masih dikatakan minim dalam hal komunikasi berbahasa Inggris, oleh karena itu SMK N 1 Banyudono melalui ekstrakulikuler ECC mengharapkan bahwa dengan diadakannya kegiatan tersebut dapat mendorong siswa untuk belajar bahasa Inggris terutama mengembangkan kemampuan berbicara menggunakan bahasa Inggris. Hal ini dimaksudkan agar ketika siswa lulus dari SMK N 1 Banyudono, mereka memiliki kemampuan komunikasi baik dalam bahasa asli maupun bahasa Inggris agar kualitas sebagai lulusan sekolah kejuruan dapat dinilai lebih baik dalam dunia kerja dan para lulusan dapat bersaing dalam dunia kerja, kuliah maupun wirausaha dengan mengantongi berbagai kemampuan dari sekolah sehingga mereka dapat dipertimbangan sebagai calon pekerja, mahasiswa maupun wirausahawan yang unggul di masyarakat.

Kegiatan visiting foreigner dalam pengembangan speaking skill merupakan sebuah kegiatan untuk meningkatkan kemampuan berbicara siswa SMK N 1 Banyudono yang diwadahi sekolah dalam kegiatan ekstrakulikuler English Conversation Club (ECC) dimana dalam kegiatannya siswa didorong untuk melakukan praktik berbicara dengan warga asing atau penutur asing sehingga siswa dapat berbicara dengan bahasa Inggris dan juga menumbuhkan sikap percaya diri siswa.

Dampak kegiatan visiting foreigner dalam pengembangan speaking skill diantaranya sebagai berikut:

1. Meningkatkan kemampuan berbicara bahasa Inggris dengan lancar.

2. Menambah kosa kata

3. Memperluas jaringan komunikasi

4. Mengetahui perkembangan komunikasi saat ini

Bahasa Inggris merupakan bahasa yang sangat penting untuk dikuasai oleh seseorang dalam menghadapi kedinamisan kehidupan sosial masyarakat, khususnya kemampuan berbahasa Inggris secara lisan merupakan hal yang sangat penting untuk dikuasai dalam komunikasi resmi maupun keseharian karena dari sanalah seseorang dapat dikatakan mampu atau berhasil dalam mempelajari bahasa Inggris (Derakshan, A, dkk. 2016).

SIMPULAN

Dari hasil observasi dan diskusi maka kesimpulan yang didapatkan adalah kegiatan visiting foreigner ECC SMK N 1 Banyudono dapat membantu siswa untuk mengembangkan kemampuan berbicara bahasa Inggris serta membekali siswa kepercayaan diri dalam berkomunikasi dengan orang asing sehingga siswa dapat 
terus menggali potensi komunikasi menggunakan bahasa Inggris. Kegiatan ini dapat terus dilanjutkan sampai pada tahap follow up sehingga siswa dapat lebih memahami dan mengevaluasi kegiatan yang telah mereka lakukan.

\section{DAFTAR PUSTAKA}

Alim, Sahirul, H. (2018). Improving Student Speaking Ability Through the Integrated English Lessonn Method: Demonstrative Presentation. Jurnal Invoish. Madura.

Biria, Reza. (2018). Exploring the Relationship Between Life Quality and Speaking Ability of Iranian Intermediate EFL Learners. International Journal of Foreign Language Teaching and Research. Iran.

Derakshan, A, dkk. (2016). Developing EFL Learner's Speaking Ability, Accuracy and Fluencey. English Language and Literature Studies. 6(2), 925-4776.

Lestari, Endah Dewi. (2018). Manajemen Persekolahan: Pengembangan Song, Word Map, Game dan Role Play Dalam Pembelajaran Bahasa Inggris Untuk Meningkatkan Speaking Skill Dan Keterlibatan Siswa Kelas III SD Kristen Pelita Bangsa Lumajang. Jurnal Manajemen Bisnis, 13(1), 107-130.

Meylinda, Frista., Yuwana, Setya., \& Sukartiningsih, Wahyu. (2016). Pengembangan Media Pembelajaran Keterampilan Berbicara dengan Program Adobe Flash untuk Siswa Kelas V SD. . Jurnal Review Pendidikan Dasar, 2(3), 256-264.

Permana, Erwin Putera. (2015). Pengembangan Media Pembejaran Boneka Kaus Kaki untuk Meningkatkan Keterampilan Berbicara Siswa Kelas II Sekolah Dasar. Profesi Pendidikan Dasar, 2(2), 133-140.

Prayitno, Siswoto Hadi., \& Ayu, Sylene Meilita. (2018). Hubungan Antara Kepribadian Introvert Dan Ekstrovert Dengan Speaking Skill Mahasiswa Prodi D III Keperawatan Tahun Akademik 2017/2018. Jurnal Insight Fakultas Psikologi Universitas Muhammadiyah Jember, 14(1), 60-73.

Ramadhani, Rizki Putri., Hs. Widodo., \& Harsiati, Titik. (2016). Pengembangan Bahan Ajar Keterampilan Berbicara Bahasa Indonesia Bagi Penutur Asing Tingkat Pemula. Jurnal Pendidikan, 1(3), 326-337.

Terasne., \& Setianingsih, Tri. (2020). The Effect Of Problem Based Solving Strategy Towards Students' Speaking Skill. Jurnal Paedagogy, 7(3), 151-155.

Uchihara, Takumi. Jon, Clenton. (2018). Inverstigating The Role of Vocabulary Size in Second Language Speaking Ability. Language Teaching Research. Jepang. 